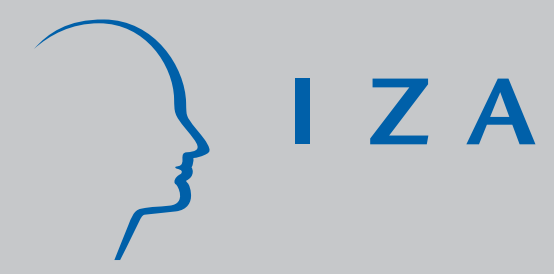

IZADP No. 3923

Downward Nominal Wage Rigidity in Services:

Direct Evidence from a Firm Survey

Daniel Radowski

Holger Bonin

J anuary 2009 


\title{
Downward Nominal Wage Rigidity in Services: Direct Evidence from a Firm Survey
}

\author{
Daniel Radowski \\ Deutsche Bundesbank
}

Holger Bonin

ZEW and IZA

Discussion Paper No. 3923
January 2009

IZA

P.O. Box 7240

53072 Bonn

Germany

Phone: +49-228-3894-0

Fax: +49-228-3894-180

E-mail: iza@iza.org

\begin{abstract}
Any opinions expressed here are those of the author(s) and not those of IZA. Research published in this series may include views on policy, but the institute itself takes no institutional policy positions.

The Institute for the Study of Labor (IZA) in Bonn is a local and virtual international research center and a place of communication between science, politics and business. IZA is an independent nonprofit organization supported by Deutsche Post World Net. The center is associated with the University of Bonn and offers a stimulating research environment through its international network, workshops and conferences, data service, project support, research visits and doctoral program. IZA engages in (i) original and internationally competitive research in all fields of labor economics, (ii) development of policy concepts, and (iii) dissemination of research results and concepts to the interested public.
\end{abstract}

IZA Discussion Papers often represent preliminary work and are circulated to encourage discussion. Citation of such a paper should account for its provisional character. A revised version may be available directly from the author. 
IZA Discussion Paper No. 3923

January 2009

\section{ABSTRACT}

\section{Downward Nominal Wage Rigidity in Services: Direct Evidence from a Firm Survey}

The paper uses a new German employer survey on wage setting practices to analyze incidence and sources of nominal wage rigidity in services vs. manufacturing. We observe that wage freezes are significantly more frequent and wage cuts less frequent in services. Reasons preventing wage cuts reported by employers suggest that fear of excess worker turnover could explain this distinct behavior.

JEL Classification: J31

Keywords: nominal wage rigidity, efficiency wages, manufacturing and services, Germany

Corresponding author:

Daniel Radowski

Deutsche Bundesbank

Research Department

P.O. Box 100602

D-60006 Frankfurt am Main

Germany

E-mail: daniel.radowski@bundesbank.de 


\section{Introduction}

The paper analyses the incidence and sources of downward nominal wage rigidity using direct evidence from a survey among German employers on wage setting behavior. It adds to the literature on downward wage rigidity based on firm level surveys (Campbell and Kamlani (1997), Bewley (1999), Agell and Bennmarker (2007)), by focusing on sector differences. In contrast to Franz und Pfeiffer (2006) our data does not only cover the reasons of wage rigidity but also the incidence at the firm. Our findings suggest that wage cuts are significantly less frequent in services than in manufacturing, and that fear of higher worker turnover could explain the difference between sectors.

\section{Data}

We employ the recent Wage and Price Setting Survey of Deutsche Bundesbank, conducted in October 2007. The survey was carried out in written form among the firms participating in the monthly ifo Business Cycle Survey. The respondents are CEOs, controllers or personnel managers.

Beyond basic firm characteristics, the survey directly asks about the incidence of wage freezes and wage cuts, as follows: "Over the past five years, has the base wage of some employees in your firm ever been frozen (cut) instead of being increased?” By linking the incidence of wage freezes (cuts) to the standard of a wage increase, positive answers imply a higher degree of wage flexibility. This concept differs from that common in micro econometric studies which treats wage freezes as an alternative to wage cuts and thus indicate wage rigidity.

As the survey refers to direct remuneration excluding bonuses, earnings flexibility is probably larger than measured (base) wage flexibility. Due to the five year time span covered, annual rates of wage freezes or cuts will be smaller than the reported rates.

The survey also asked for reasons preventing wage cuts: "Even in times of bad economic conditions or high unemployment firms tend to rarely cut their employees' wages, although this could help firms to survive in the market and help to save jobs. Which reasons prevent you from cutting base wages?” Seven reasons for downward wage rigidity are listed, namely efficiency wages, labor regulation, collective agreements, loss of reputation, excessive worker 
turnover, implicit wage smoothing and improved outside options for workers. Firms are asked to mark the three most important reasons.

Sampling in the survey is done "by purpose”, i.e., is not fully representative but still designed to yield a balanced picture of manufacturing and services. Services covered include both highskilled labor (like IT) and low-skilled labor intensive services (like hotels/restaurants). Larger and older firms are overrepresented in the sample.

The survey covers 661 services firms and 1,149 manufacturing firms. Firms report for product groups, which in most cases coincide with plants. Most firms are single plant firms. In firms with several plants, the survey refers to the largest product group.

Descriptive statistics reveal the expected sectoral differences. Firms in services are significantly smaller and younger. The labor cost share, approximating labor intensity, is larger in services (43\%) than in manufacturing (32\%). The labor cost gap also reflects a markedly higher share of less educated, blue collar workers in manufacturing. Manufacturing firms are more often covered by collective agreements (43\%) than services firms (38\%). Parttime and fixed-term work is more frequent in services. Firms in services perceive labor markets more often as tight (26\%) than the ones in manufacturing (17\%). Worker turnover rates are much higher in services (31\%) than in manufacturing (13\%).

\section{Incidence and Sources of Wage Rigidity}

According to our survey, nominal wage cuts are rather rare. Only $13 \%$ of firms in services and $16 \%$ of firms in manufacturing have ever cut their wages over a five year span. Wage freezes instead of wage increases are quite common. $57 \%$ of firms in services and $46 \%$ of firms in manufacturing report zero wage changes. Thus wages appear markedly more flexible in services than in manufacturing.

To test whether sector differences are statistically significant after controlling for specific firm characteristics, we run binary probit models, see Table 1.

Firms in a favorable state of business, indicated by growing employment, are less inclined to freeze wages. Wages freezes are significantly less common in firms covered by collective agreement and larger firms. They are more prevalent in firms with a higher labor cost share and firms facing strong price competition. Labor intensive firms tend to have a higher wage 
bill and thus incentives to adjust at the labor cost margin are relatively large. Firms in strong price competition have more difficulties to adjust at the price margin and may therefore prefer the labor cost margin. There is no apparent correlation between the incidence of wage freezes and worker turnover, the total of hiring and separation rates. The propensity to wage freezes is also unrelated to firms' reported difficulties to hire workers.

Sector-specific firm characteristics, like the lower rate of unionization, contribute little to explaining the higher incidence of wage freezes in services. At the mean, the propensity to freeze wages is 9.2 percentage points higher than in manufacturing, while the unconditional sector gap amounts to 11 percentage points. Inclusion of the significant services dummy does not markedly alter the impact of the firm characteristics affecting wage freezes, comparing models (1) and (2).

Turning to wage cuts, we find little systematic correlation with firm characteristics. Given our sample size and the scarcity of the event, lack of statistical significance at conventional levels is not too surprising. If judged by the point estimates, variables that drive wage freezes (employment growth, collective bargaining agreement, price competition) seem to drive wage cuts in the same direction, though the impact on wage cuts is smaller. The rather large point estimate may indicate that a higher turnover rate yields fewer wage cuts.

After controlling for sector-specific firm characteristics, wage cuts are significantly less common (by 6.4 percentage points) in services than in manufacturing. Given that wage freezes are more common at the same time, a suggestive interpretation would be that firms in services resort to wage freezes as they have difficulties to implement wage cuts. This leads to the question whether there are special reasons preventing wage cuts in services.

\subsection{Reasons Preventing Wage Cuts}

According to our survey, five out of the seven reasons preventing nominal wage cuts appear equally important in services and manufacturing. In line with the literature, loss of labor efficiency, mentioned by three in four services and manufacturing firms, is the primary concern. Three in five firms (60\%) mention labor regulation. Loss of reputation (24\%), implicit wage smoothing (16-18\%) and improved outside options (6-8\%) are also mentioned at very similar rates in the two sectors, and do not seem too relevant. 
Substantial sector differences emerge regarding two sources of wage rigidity - collective bargaining preventing wage cuts (33\% of firms in services, $45 \%$ in manufacturing), and fear of increasing quits and excess worker turnover (32\% services, 19\% manufacturing). The first observation would fit higher unionization rates in manufacturing, the second higher labor intensity, higher general worker turnover, higher share of white collar workers, and the perception of a tighter labor market in services.

In Table 2, we consider the role of sector-specific firm characteristics driving the sectorspecific responses. Models (1) and (2) substantiate that the higher incidence of the collective bargaining argument among manufacturing firms mostly reflects that collective agreements are more frequent here. Besides, larger firms in manufacturing contribute to the raw sector gap. The impact of these two variables is strong enough to render the sector differential insignificant.

Regarding the excess turnover argument, empirical findings are generally consistent with our expectations. First, the higher the share of white collar workers, the more relevant is the worker turnover argument. Better qualified workers have more outside options, and the costs of replacing more productive workers associated with hiring and training tend to be higher. Second, firms that grow in employment are markedly more aware of excess worker turnover associated with wage cuts. They need to keep quit rates low to facilitate the growth process. Third, the turnover argument is significantly less relevant in East Germany where there are fewer outside options for workers due to high levels of unemployment compared to West Germany. Perceived hiring difficulties, however, do not seem to foster fear of excess worker turnover.

The negative correlation of collective agreements on the incidence of the worker turnover argument may reflect that unionized firms are low turnover firms. First, quitting from such a firm is less attractive given the risk to move to a non-unionized firm. Second, unionized firms are a non-random sample of firms. High turnover firms have incentives to leave the collective bargaining system to facilitate labor adjustment. Thus, the collective agreement variable may cover some of the variation in worker turnover at individual firm level. This might contribute to explain why, somewhat surprisingly, the individual worker turnover rate is uncorrelated with firms mentioning the worker turnover argument.

Sector-specific firm characteristics do not explain the higher prevalence of the worker turnover argument among services firms. The sector gap conditional on characteristics is even 
wider than the raw gap, partly because of the larger firm sizes in manufacturing. As we control for individual firm level worker turnover, a suggestive explanation for the significant disparity might be the large difference in overall worker turnover rates by sector.

\section{Conclusions}

Our survey results confirm previous micro econometric evidence suggesting that wage freezes are quite common in Germany, whereas wage cuts seldom occur. Wage cuts are even rarer in services than in manufacturing. The difference is not due to peculiar firm characteristics, but fear of excess worker turnover could explain the result. Services firms mention this argument much more often, even if one controls for relevant firm characteristics. A suggestive interpretation of this behavior is that it reflects high actual turnover rates in services. In our data, they are more than twice as high as in manufacturing.

\section{References}

Agell, J. and H. Bennmarker, 2007, Wage Incentives and Wage Rigidity: A Representative View from Within, Labour Economics 14, 347-369.

Bewley, T.F., 1999, Why Do Wages Not Fall During a Recession?, Harvard University Press.

Campbell, C.M. and K.S. Kamlani, 1997, The Reason for Wage Rigidity: Evidence from a Survey of Firms, Quarterly Journal of Economics 112(3), 759-789.

Franz, W. and F. Pfeiffer, 2006, Reasons for Wage Rigidity in Germany, LABOUR - Review of Labour Economics and Industrial Relations 20(2), 255-284. 
Table 1: Probit Estimates on Wage Freezes and Wage Cuts

\begin{tabular}{lcccc}
\hline \hline & \multicolumn{2}{c}{ Incidence of } & Wage Freezes & \multicolumn{2}{c}{$\begin{array}{c}\text { Incidence of Wage Cuts } \\
\text { Firm Characteristics }\end{array}$} & $(1)$ & $(2)$ & $(3)$ & $(4)$ \\
\hline \hline log Number of Employees & $-0.047^{* * *}$ & $-0.040^{* *}$ & 0.011 & 0.007 \\
Employment Growth Rate & $-0.412^{* *}$ & $-0.413^{* *}$ & -0.205 & -0.203 \\
Worker Turnover Rate & 0.043 & 0.032 & $-0.161^{*}$ & -0.127 \\
Firm Age & 0.001 & 0.001 & 0.000 & 0.000 \\
Labor Cost Share & $0.003^{* * *}$ & $0.003^{* * *}$ & 0.000 & 0.000 \\
Share of Blue Collar Workers & 0.020 & 0.063 & -0.025 & -0.057 \\
Hiring Difficulties & 0.036 & 0.036 & 0.048 & 0.048 \\
Collective Agreement & $-0.200^{* * *}$ & $-0.207^{* * *}$ & -0.043 & -0.040 \\
East German & -0.014 & -0.002 & $-0.062^{* * *}$ & $-0.068^{* *}$ \\
Export Share & $-0.001^{* *}$ & -0.001 & -0.000 & -0.000 \\
Strong Price Competition & $0.097^{* * *}$ & $0.099^{* * *}$ & $0.044^{*}$ & $0.045^{*}$ \\
Service Sector & $\mathrm{NO}$ & $0.092^{*}$ & $\mathrm{NO}$ & $-0.064^{*}$ \\
\hline Observations & 832 & 832 & 837 & 837 \\
Pseudo R & 0.077 & 0.081 & 0.032 & 0.037 \\
\hline \hline
\end{tabular}

Notes: Marginal effects. ${ }^{* * *}$ denotes significance at the $1 \%$ level, ${ }^{* *}$ at $5 \%$, ${ }^{*}$ at $10 \%$. 
Table 2: Probit Estimates on Reasons Preventing Wage Cuts

\begin{tabular}{|c|c|c|c|c|}
\hline \multirow[b]{2}{*}{ Firm Characteristics } & \multicolumn{2}{|c|}{ Collective Bargaining Agreement } & \multicolumn{2}{|c|}{ Excess Worker Turnover } \\
\hline & (1) & $(2)$ & (3) & (4) \\
\hline log Number of Employees & $0.094 * * *$ & $0.093 * * *$ & $0.025^{*}$ & $0.036 * * *$ \\
\hline Employment Growth Rate & -0.294 & -0.295 & $0.284^{*}$ & $0.285^{*}$ \\
\hline Worker Turnover Rate & 0.066 & 0.069 & 0.015 & 0.002 \\
\hline Firm Age & 0.001 & 0.001 & $-0.001 *$ & -0.000 \\
\hline Labor Cost Share & -0.001 & -0.001 & 0.001 & 0.000 \\
\hline Share of Blue Collar Workers & 0.071 & 0.065 & $-0.252 * * *$ & $-0.185 * * *$ \\
\hline Hiring Difficulties & $-0.102 *$ & $-0.103^{*}$ & 0.010 & 0.015 \\
\hline Collective Agreement & $0.600 * * *$ & $0.601^{* * *}$ & $-0.157 * * *$ & $-0.165 * * *$ \\
\hline East German & -0.036 & -0.036 & $-0.090 * *$ & $-0.076 * *$ \\
\hline Export Share & -0.000 & -0.000 & -0.000 & 0.000 \\
\hline Strong Price Competition & 0.024 & 0.023 & 0.001 & 0.001 \\
\hline Service Sector & $\mathrm{NO}$ & -0.014 & $\mathrm{NO}$ & $0.147^{* * *}$ \\
\hline Observations & 792 & 792 & 792 & 792 \\
\hline Pseudo $\mathrm{R}^{2}$ & 0.380 & 0.380 & 0.095 & 0.101 \\
\hline
\end{tabular}

Notes: Marginal effects. $* * *$ denotes significance at the $1 \%$ level, $* *$ at $5 \%, *$ at $10 \%$. 